\title{
ANALISIS MANAJEMEN LABA YANG DIPENGARUHI OLEH KOMITE AUDIT DAN FIRM SIZE PERUSAHAAN LQ45 TAHUN 2015 - 2019
}

\author{
RAKHMAWATI OKTAVIANNA*, EKA RIMA PRASETYA \\ Universitas Pamulang, Tangeran Selatan, Indonesia \\ *Email:dosen01146@unpam.ac.id
}

\begin{abstract}
Managers manipulate earnings by increasing the number of reported earnings so that earnings information about the company becomes a good signal for investors to invest their shares and increase trust in creditors. The purpose of this study is to examine the effect of the audit committee and firm size on earnings management at LQ45 companies listed on the Indonesia Stock Exchange (BEI) in 2015 - 2019. The type of research in this study uses a quantitative approach. Data collection using the document method with secondary data sources. Determination of the sample using purposive sampling method, with a total sample of 130 samples. The data analysis technique used is the multiple linear regression test using the program Eviews 10. The results of this study are that the audit committee and firm size together have an effect on earnings management, the audit committee has no effect on earnings management and firm size has an effect on earnings management in the company. LQ45 which is listed on the Indonesia Stock Exchange (IDX) in 2015 - 2019.
\end{abstract}

Keywords: Earnings Management; Audit Committee; Firm Size

\section{PENDAHULUAN}

Laporan keuangan disusun guna menyediakan informasi terkait dengan posisi keuangan, perubahan posisi keuangan dan kinerja suatu entitas sehingga laporan keuangan tersebut memberikan manfaat bagi para pengguna dalam mengambil keputusan. Manfaat laporan keuangan tersebut menjadi optimal bagi investor apabila investor dapat menganalisis lebih lanjut melalui perolehan laba yang diperoleh, di mana laba merupakan salah satu informasi potensial yang sangat penting baik untuk internal perusahaan maupun pihak eskternal. Manajemen laba merupakan proses untuk mengambil langkah tertentu yang disengaja dalam batasbatas prinsip akuntansi berterima umum untuk menghasilkan tingkat yang diinginkan dari laba yang dilaporkan (Sulistyanto, 2008; Davidson, Stickney dan Weil, 1987). Karena informasi laba tersebut sangat berpengaruh, seringkali memungkinkan pihak manajemen melakukan tindakan untuk memodifikasi informasi laba untuk dapat menghasilkan informasi sesuai yang diinginkan demi

* Corresponding author's e-mail: dosen01146@unpam.ac.id

http://openjournal.unpam.ac.id/index.php/JIA 
Jurnal Ilmiah Akuntansi Universitas Pamulang - Vol. 9, No. 1, Januari 2021 Oktavianna \& Prasetya

mencapai tujuan tersendiri. Tindakan tersebut biasa dikenal dengan manajemen laba (earnings management) (Ali. S \& Adityawarman 2014)

Perbuatan ini dikategorikan sebagai kecurangan karena secara sadar dilakukan manajer perusahaan agar stakeholder yang ingin mengetahui kondisi ekonomi perusahaan tertipu karena memperoleh informasi palsu. Sementara para akademisi berargumen bahwa pada dasarnya manajemen laba merupakan dampak dari kebebasan seorang manajer untuk memilih dan menggunakan metode akuntansi tertentu ketika mencatat dan menyusun informasi dalam laporan keuangan.

Manajemen laba merupakan pemilihan kebijakan akuntansi secara alamiah dapat dimaksimalkan utilitas mereka atau nilai pasar perusahaan. Manajemen memanfaatkan fleksibelitas yang diperbolehkan oleh standar akuntansi dalam menyusun laporan keuangan untuk modifikasi laba yang dilaporkan. Namun disayangkan dalam praktiknya, manajemen laba seringkali digunakan untuk kepentingan pribadi oleh pihak manajemen perusahaan (Ali. S \& Adityawarman, 2014; Scoot, 2006).

Semua keputusan manajerial yang seharusnya diambil untuk kepentingan dan kesejahteraan stakeholder diselewengkan demi kepuasan pribadi (Sulistyanto, 2008). Laporan laba pada perusahaan PT. Garuda Indonesia Tbk (GIAA) di anggap janggal sehingga Otoritas Jasa Keuangan (OJK) meminta Bursa Efek Indonesia untuk periksa manajemen PT. Garuda Indonesia Tbk (GIAA). Kasus ini bermula dari laporan keuangan perusahaan yang membukukan laba bersih US\$.809.846 pada tahun 2018 atau setara Rp.11,49 miliar (kurs Rp.14.200/US\$). Total beban usaha yang dibukukan perusahaan tahun lalu mencapai US\$ 4,58 miliar. Angka ini lebih besar US\$206,08 juta dibanding total pendapatan tahun 2018, seharusnya perusahaan tersebut merugi. (Donald Banjanahor. 2019, Laporan Laba Janggal, OJK minta BEI periksa manajemen Garuda). Kasus lainnya pada PT. Perusahaan Listrik Negara (Persero) atau PLN berhasil mencetak laba bersih Rp.11,56 triliun sepanjang 2018. Laba itu naik sebesar 162,30 persen atau hampir tiga kali lipat dari laba 2017 yakni Rp.4,42 triliun. Padahal, pada kuartal III 2019, PLN masih mengantongi rugi sebesar Rp.18,48 triliun akibat rugi selisih kurs sebesar Rp.17,32 triliun. Terjadi keanehan dalam laporan keuangan di dua perusahan tersebut.

Pada penelitian ini komite audit dan firm size digunakan sebagai variabel untuk menganalisis manajemen laba perusahaan karena seharusnya keberadaan komite audit disuatu perusahaan memiliki peranan penting dalam memastikan keakuratan laporan keuangan perusahaan tersebut. Untuk meningkatkan kualitas laporan keuangan, efektivitas dari pengawasan komite audit dapat mengurangi praktik manajemen laba (Lestari \& Murtanto, 2017). Sedangkan firm size atau ukuran perusahaan juga menjadi salah satu yang mendorong terjadinya tindakan manajemen laba. Ukuran perusahaan adalah suatu indikator yang dapat menunjukkan suatu kondisi atau karakteristik suatu organisasi atau perusahaan di mana terdapat beberapa parameter yang dapat digunakan untuk menentukan ukuran (besar/kecilnya) suatu perusahaan, seperti banyaknya jumlah karyawan yang digunakan dalam perusahaan untuk melakukan aktivitas operasional perusahaan, jumlah aktiva yang dimiliki perusahaan, total penjualan yang dicapai oleh perusahaan dalam suatu periode, nilai pasar perusahaan, nilai buku perusahaan serta

* Corresponding author's e-mail: dosen01146@unpam.ac.id

http://openjournal.unpam.ac.id/index.php/JIA 
Jurnal Ilmiah Akuntansi Universitas Pamulang - Vol. 9, No. 1, Januari 2021 Oktavianna \& Prasetya

jumlah saham yang beredar(Manggau, 2016; Riani Et al, 2020). Semakin besar ukuran perusahan biasanya informasi yang tersedia untuk investor dalam pengambilan keputusan sehubungan dengan investasi dalam saham perusahaan tersebut semakin banyak. Dengan hasil penelitian, diharapkan perusahaan akan dapat meningkatkan manajemen labanya dan bisa memperbaiki laporan keuangan nya untuk pihak yang berkepentingan dan dapat menjadikan dasar pengambilan keputusan.

\section{LANDASAN TEORI}

Teori akuntansi positif dijelaskan tentang fenomena akuntansi yang diamati berdasarkan pada alasan-alasan yang menyebabkan terjadinya suatu peristiwa. Teori ini bertujuan untuk menjelaskan dan memprediksi konsekuensi yang terjadi jika manajer menentukan pilihan tertentu (Dinuka dan Zulaikha, 2014). Secara umum ada beberapa motivasi yang mendorong manajer untuk berperilaku oportunis, yaitu motivasi bonus, kontrak, politik, pajak, CEO, IPO atau SEO, dan mengkomunikasikan informasi ke investor. Dalam teori akuntansi positif ini terdapat dorongan atau motivasi yang menjadi dasar terjadinya manajemen laba. Motivasi tersebut salah satunya adalah sistem bonus, yang mengharuskan manajer dengan segala cara dan upaya melakukan manajemen laba untuk mendapatkan bonus yang optimal.

Earnings Management atau Manajemen laba dapat didefinisikan sebagai perilaku manajer untuk "bermain" dengan komponen discretionary accruals dalam menentukan besarnya laba. earnings management adalah pilihan kebijakan akuntansi oleh manajer dalam rangka mencapai tujuan tertentu (Kodriyah dan Fitri, 2017; Scott, 2003).

Dalam peraturan Otoritas Jasa Keuangan (OJK) Nomor.55/POJK.04/2015 Pasal 1 tentang Pembentukan dan Pedoman Pelaksanaan Kerja Komite Audit disebutkan bahwa yang dimaksud dengan komite audit adalah komite yang dibentuk oleh dan bertanggung jawab kepada dewan komisaris dalam membantu pelaksanaan tugas dan fungsi dewan komisaris. Keberadaan komite audit bermanfaat dalam menjamin transparasi, keterbukaan laporan keuangan, keadilan bagi stakeholder, dan pengungkapan informasi yang dilakukan oleh manajemen (Nabilah dan Daljono, 2012).

Firm Size atau Ukuran perusahaan adalah besarnya laba yang dihasilkan oleh perusahaan dalam satu tahun buku, di mana penjualan lebih besar daripada biaya variabel dan biaya tetap, maka akan diperoleh jumlah pendapatan sebelum pajak. Sebaliknya jika penjualan lebih kecil daripada biaya variabel dan biaya tetap maka perusahaan menderita kerugian (Makaombohe dkk, 2014; Brigham dan Houston, 2001). Ukuran perusahaan merupakan salah satu indikator yang digunakan investor dalam menilai assets maupun kinerja perusahaan. Semakin besar aset yang dimiliki perusahaan, maka perusahaan tersebut dianggap sudah mencapai fase dewasa dan memiliki prospek yang baik untuk jangka waktu yang lama (Yulianti, 2020)

Adapun hipotesis pada penelitian ini adalah:

* Corresponding author's e-mail: dosen01146@unpam.ac.id

http://openjournal.unpam.ac.id/index.php/JIA 
Jurnal Ilmiah Akuntansi Universitas Pamulang - Vol. 9, No. 1, Januari 2021 Oktavianna \& Prasetya

H1: Komite Audit dan Firm Size berpengaruh secara simultan terhadap Manajemen Laba.

H2: $\quad$ Komite Audit berpengaruh terhadap Manajemen Laba.

H3: Firm Size berpengaruh terhadap manajemen laba

\section{METODE PENELITIAN}

Jenis penelitian ini adalah penelitian pendekatan kuantitatif, dengan menggunakan metode deskriptif. Data yang digunakan adalah data sekunder karena penelitian ini menggunakan data laporan keuangan perusahaan yang masuk dalam daftar indeks LQ45 yang terdaftar di Bursa Efek Indonesia yang dapat diakses melalui situs (www.idx.co.id) tahun 2015-2019. Perusahaan indeks LQ45 merupakan perusahaan dengan likuiditas tinggi dan kapitalisasi pasar besar serta didukung oleh fundamental perusahaan yang baik.

\section{Teknik Pengumpulan data}

Penelitian ini mengambil data dengan cara mengakses situs (www.idx.co.id) dan memilih perusahaan yang masuk dalam daftar indeks LQ45 yang terdaftar di Bursa Efek Indonesia tahun 2015-2019. Dan ditambahkan dengan studi pustaka dari beberapa buku, penelitian terdahulu dan lainnya yang berhubungan dengan masalah dan tujuan penelitian.

\section{Operasional Variabel Penelitian}

Variabel dependen dalam penelitian ini adalah manajemen laba sedangkan variabel independen dalam penelitian ini adalah komite audit dan firm size. Manajemen laba diukur dengan model Modified Jones :

\section{DAit $=$ TACit $/$ At -1 - NDAit}

Sebelum diperoleh rumus tersebut maka harus melakukan tiga tahapan adalah sebagai berikut:

1. Tahap 1 dengan mencari total akrual dengan cara laba bersih dikurangi dengan arus kas kegiatan operasi adalah sebagai berikut:

$$
\text { TACit }=\text { Niit }- \text { CFOit }
$$

2. Tahap 2 nilai total akrual (ACCR) diestimasi dengan persamaan regresi sebagai berikut:

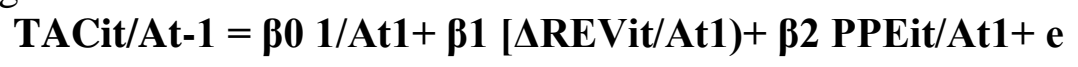

3. Tahap 3 dengan menggunakan koefisien regresi di atas nilai non discretionary accrual (NDA) dapat dihitung dengan rumus :

NDAit $=\beta 01 /$ At1 $+\beta 1[\Delta$ REVit/At1 $-\Delta$ RECit/At1 $]+\beta 2$ PPEit/At1

Sehingga Discretionary Accruals (DA) dapat dihitung sebagai berikut :

Keterangan:

$$
\text { DAit = TACit/At-1- NDAit }
$$

TACit: Total akrual

* Corresponding author's e-mail: dosen01146@unpam.ac.id

http://openjournal.unpam.ac.id/index.php/JIA 
Jurnal Ilmiah Akuntansi Universitas Pamulang - Vol. 9, No. 1, Januari 2021 Oktavianna \& Prasetya

Niit : Laba bersih

CFOit: $\quad$ Arus kas dari kegiatan operasi

At1: $\quad$ Total aset untuk perusahaan i pada akhir tahun t-1

$\triangle \mathrm{REV}: \quad$ Perubahan pendapatan dari tahun $\mathrm{t}-1$ ke tahun $\mathrm{t}$

$\triangle R E C$ : Perubahan nilai piutang bersih dari tahun $\mathrm{t}-1$ ke tahun $\mathrm{t}$

PPE: Nilai aktiva tetap pada tahun $\mathrm{t}$

NDA: Non-Discretionary Accruals

DA: Discretionary Accruals

Komite audit diukur dengan :

Komite Audit $=\frac{\text { Jumlah Komite Audit Independen }}{\text { Jumlah Seluruh Anggota Komite Audit }}$

Firm size diukur dengan $:$ SIZE $=$ Ln Total Aset

\section{Teknik Penentuan Sampel}

Populasi pada penelitian ini adalah perusahaan yang masuk dalam daftar indeks LQ45 Tahun 2015-2019. Teknik yang digunakan dalam penentuan sampel ini adalah purposive sampling. Dengan kriteria:

1. Perusahaan indeks LQ45 yang terdaftar di Bursa Efek Indonesia periode tahun 2015-2019.

2. Perusahaan indeks LQ45 yang mempublikasikan laporan keuangannya di Bursa Efek Indonesia periode tahun 2015-2019 secara berturut-turut.

3. Perusahaan indeks LQ45 yang menyajikan laporan keuangan dalam mata uang rupiah periode tahun 2015-2019.

\section{Teknik Analisis Data}

Penelitian ini menggunakan teknik analisis kuantitatif dan perhitungannya menggunakan metode statistik yang dibantu dengan program eviews 10. Dengan beberapa tahapan:

1. Statistik deskriptif akan memberikan gambaran atau deskripsi umum dari variabel penelitian, yaitu mengenai central tendency yaitu nilai rata-rata (mean) dan ukuran dispersi yaitu standar deviasi, nilai maksimum dan nilai minimum.

2. Estimasi Model Regresi Data Panel. Terdapat tiga model yang dapat digunakan untuk melakukan regresi data panel. Ketiga model tersebut adalah Pooled OLS/ Common Effect, Fixed Effect dan Random Effect.

3. Pemilihan model regresi data panel untuk memilih model mana yang terbaik diantara ketiga model tersebut, yaitu dengan cara dilakukan uji Chow, uji Hausman, dan uji Lagrange Multiplier.

4. Uji asumsi klasik merupakan prasyarat analisis regresi data panel, yang meliputi Uji Normalitas, Uji Multikolinieritas, Uji Heteroskedastisitas dan Uji Autokorelasi.

* Corresponding author's e-mail: dosen01146@unpam.ac.id

http://openjournal.unpam.ac.id/index.php/JIA 
Jurnal Ilmiah Akuntansi Universitas Pamulang - Vol. 9, No. 1, Januari 2021 Oktavianna \& Prasetya

5. Analisis Koefisien Determinasi. Koefisien determinasi (R2) pada dasarnya mengukur seberapa jauh kemampuan model dalam menerangkan variasi variabel dependen.

6. Analisis Regresi data panel, $\mathrm{Y}=\alpha+\mathrm{bXit}+\mathrm{e}$ di mana $\alpha$ : Konstanta

$\mathrm{X}$ : Variabel independen

$\beta$ : Koefisien regresi variabel independen

e: Error term

t: Waktu

i: Perusahaan

7. Uji hipotesis

\section{ANALISIS DATA DAN PEMBAHASAN}

\section{Pemilihan Model Regresi Data Panel Uji Chow}

Redundant Fixed Effects Tests

Tabel 1. Uji Chow

Equation: Untitled

Test cross-section fixed effects

\begin{tabular}{lrrr}
\hline \hline Effects Test & Statistic & d.f. & Prob. \\
\hline \hline Cross-section F & 23.116609 & $(25,102)$ & 0.0000 \\
Cross-section Chi-square & 246.609391 & 25 & 0.0000 \\
\hline \hline
\end{tabular}

Nilai probabilitas $\mathrm{F}<0,05$ sehingga model yang sesuai dari hasil Uji Chow yaitu fixed effects

\section{Uji Hausman}

\section{Tabel 2. Uji Hausman}

Correlate Random Effects - Hausman Test

Equation Untitled

Test cross-section random effects

\begin{tabular}{lccr}
\hline \hline Test Summary & Chi-Sq. Statistic & Chi-Sq. d.f. & Prob. \\
\hline \hline Cross-section random & 17.676126 & 2 & 0.0001 \\
\hline \hline
\end{tabular}

Nilai probabilitas yaitu $<0,05$ maka metode yang kita pilih adalah fixed effect. 
Jurnal Ilmiah Akuntansi Universitas Pamulang - Vol. 9, No. 1, Januari 2021 Oktavianna \& Prasetya

\section{Uji Asumsi Klasik}

\section{Uji normalitas}

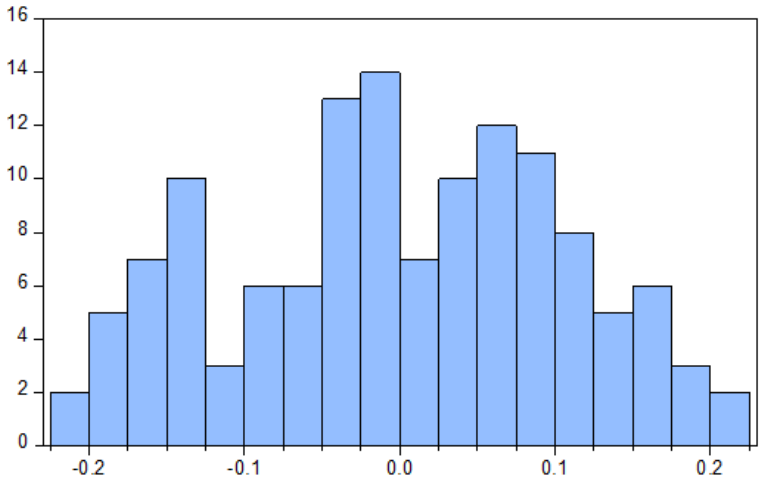

\begin{tabular}{|c|c|}
\hline \multicolumn{2}{|c|}{$\begin{array}{l}\text { Series: Standardized Residuals } \\
\text { Sample } 20152019\end{array}$} \\
\hline Mean & $-9.93 e-18$ \\
\hline Median & -0.001647 \\
\hline Maximum & 0.209059 \\
\hline Minimum & -0.212173 \\
\hline Std. Dev. & 0.106414 \\
\hline Skewness & -0.112160 \\
\hline Kurtosis & 2. 150934 \\
\hline Jarque-Bera & 4.177510 \\
\hline Probability & 0.123841 \\
\hline
\end{tabular}

\section{Gambar 1. Uji Normalitas}

Nilai Jarque-Bera dan Probabilitynya 0.123841>0.05, artinya data yang digunakan berdistribusi normal

\section{Uji Heterokedasitas}

\section{Tabel 3. Uji Heterokedasitas}

\begin{tabular}{|c|c|c|c|c|}
\hline Variable & Coefficient & Std. Error & t-Statistic & Prob. \\
\hline $\mathrm{X} 1$ & 0.041971 & 0.049785 & 0.843038 & 0.4012 \\
\hline $\mathrm{X} 2$ & 0.026651 & 0.015835 & 1.682993 & 0.0954 \\
\hline $\mathrm{C}$ & -0.800646 & 0.514109 & -1.557347 & 0.1225 \\
\hline
\end{tabular}

Hasil dari probalititas data resudial absolutenya menunjukan $>0.05$, artinya tidak terjadi heterokedasitas.

\section{Uji Multikolinearitas}

\section{Tabel 4. Uji Multikolinearitas}

\begin{tabular}{cccc} 
Variable & $\begin{array}{c}\text { Coefficient } \\
\text { Variance }\end{array}$ & $\begin{array}{c}\text { Uncentered } \\
\text { VIF }\end{array}$ & $\begin{array}{c}\text { Centered } \\
\text { VIF }\end{array}$ \\
\hline \hline $\mathrm{C}$ & 1.291609 & 60806.14 & NA \\
$\mathrm{X} 1$ & 0.011956 & 227.3985 & 1.094080 \\
$\mathrm{X} 2$ & 0.001229 & 58447.00 & 1.094080 \\
\hline \hline
\end{tabular}

Nilai VIF $<0.8$, artinya tidak terjadi multikolinearitas pada data penelitian 
Jurnal Ilmiah Akuntansi Universitas Pamulang - Vol. 9, No. 1, Januari 2021 Oktavianna \& Prasetya

\title{
Uji Autokorelasi
}

\author{
Durbin-Watson stat \\ 2.165888 \\ $\mathrm{dL}=1.6825 \mathrm{dU}=1.74494-\mathrm{dL}=2.31754-\mathrm{dU}=2.2551$
}

di mana nilai durbin watson diantara dU dan 4-dU, artinya tidak terjadi autokorelasi $1.7499<2.165<2.255$

\section{Uji Hipotesis}

\section{Tabel 5. Uji Regresi}

\begin{tabular}{|c|c|c|c|c|c|}
\hline \multicolumn{6}{|l|}{ Dependent Variable: $\mathrm{Y}$} \\
\hline \multicolumn{6}{|c|}{ Method: Panel EGLS (Cross-section weights) } \\
\hline \multicolumn{6}{|l|}{ Periods included: 5} \\
\hline \multicolumn{6}{|c|}{ Cross-sections included: 26} \\
\hline \multicolumn{6}{|c|}{$\begin{array}{l}\text { Total panel (balanced) observations: } 130 \\
\text { Linear estimation after one-step weighting matrix }\end{array}$} \\
\hline Variable & Coefficient & Std. Error & t-Statistic & Prob. & \\
\hline $\mathrm{C}$ & 2.118950 & 1.136490 & 1.864469 & 0.0651 & \\
\hline $\mathrm{X} 1$ & 0.110443 & 0.109344 & 1.010046 & 0.3149 & \\
\hline $\mathrm{X} 2$ & -0.082160 & 0.035056 & -2.343702 & 0.0210 & \\
\hline \multicolumn{6}{|c|}{ Effects Specification } \\
\hline \multicolumn{6}{|c|}{ Cross-section fixed (dummy variables) } \\
\hline \multicolumn{6}{|c|}{ Weighted Statistics } \\
\hline R-squared & 0.978580 & Mea & pendent var & & -0.711771 \\
\hline Adjusted R-squared & 0.972910 & S.D. & endent var & & 0.897223 \\
\hline S.E. of regression & 0.119673 & Sum & ared resid & & 1.460799 \\
\hline F-statistic & 172.5898 & Durk & Vatson stat & & 2.165888 \\
\hline Prob(F-statistic) & 0.000000 & & & & \\
\hline
\end{tabular}

Hasil uji regresi estimasi fixed effect, maka model regresi data panelnya yaitu: $\mathrm{Y}=2.118950+0.110443 \mathrm{X} 1+-0.082160 \mathrm{X} 2+\mathrm{e}$

1. Nilai konstanta dari hasil model regresi data panel sebesar 2.118950. Jika komite audit dan firm size bernilai nol, maka besarnya manajemen laba sebesar 2.118950 .

2. Nilai Koefisien pada model regresi data panel yaitu 0.110443 untuk komite audit dan, -0.082160 untuk firm size jadi jika terdapat kenaikan satu pada variabel komite audit maka nilai manajemen laba akan bertambah sebesar 0.110443 dan jika ada kenaikan satu pada variabel firm size maka akan mengurangi nilai manajemen laba sebesar0.082160

* Corresponding author's e-mail: dosen01146@unpam.ac.id

http://openjournal.unpam.ac.id/index.php/JIA 
Jurnal Ilmiah Akuntansi Universitas Pamulang - Vol. 9, No. 1, Januari 2021 Oktavianna \& Prasetya

3. Dari nilai Prob(F-statistic) $0.000000<0.005$, menujukkan komite audit dan firm size memiliki pengaruh secara simultan signifikan terhadap manajemen laba

4. Dari hasil penelitian yang ditunjukkan nilai komite audit variabel independen (X1) 0.3149> 0,05, maka berarti variabel komite audit tidak berpengaruh terhadap manajemen laba. Namun pada nilai firm size (X2) menunjukkan $0.0210<0.05$, maka variabel firm size berpengaruh terhadap manajemen laba.

5. Nilai koefisien determinasinya dalam penelitian ini adalah 0.978580 atau 97

$\%$. Sehingga dapat di simpulkan $97 \%$ manajemen laba dipengaruhi oleh komite audit dan firm size, sedangkan sisanya sebesar $3 \%$ dipengaruhi oleh variabel lain

\section{Pengaruh Komite Audit dan Firm Size Terhadap Manajemen Laba}

Hipotesis pertama menujukkan komite audit dan firm size memiliki pengaruh secara simultan signifikan terhadap manajemen laba. Hal ini menunjukkan bahwa manajemen laba dapat dipengaruhi oleh adanya komite audit dalam perusahaan dimana berperan dalam penentuan suatu keputusan dan ukuran perusahaan yang semakin besar ataupun kecil juga sangat mempengaruhi kebijakan perusahaan.

\section{Pengaruh Komite Audit terhadap Manajemen Laba}

Hipotesis kedua dalam penelitian ini adalah komite audit secara parsial tidak berpengaruh terhadap manajemen laba. Hasil penelitian ini sejalan dengan penelitian Nabila \& Daljono (2013) yang menyatakan tidak adanya pengaruh signifikan komite audit terhadap manajeme laba. Upaya perusahaan dalam melakukan manajemen laba tidak dapat di pengaruhi oleh adanya Komite audit. Hal ini diduga dikarenakan komite audit hanya digunakan oleh perusahaan untuk memenuhi syarat yang diajukan pemerintah. Hasil ini berbeda dengan penelitian Khurnanto \& Syafruddin (2015) yang berhasil membuktikan bahwa ada pengaruh signifikan antara komite audit dengan manajemen laba. Komite audit dianggap sebagai penghubung antara pemegang saham dan dewan komisaris dengan pihak manajemen dalam menangani masalah pengendalian.

\section{Pengaruh Firm Size terhadap Manajemen Laba}

Hipotesis ketiga dalam penelitian ini adalah firm size secara parsial berpengaruh terhadap manajemen laba. Hal ini sesuai dengan penelitian yang dilakukan oleh Makaombohe dkk (2014) yang menunjukkan hasil bahwa firm size atau ukuran perusahaan berpengaruh signifikan terhadap manajemen laba. Firm size merupakan gambaran besar kecilnya suatu perusahaan, semakin besar ukuran perusahaan maka informasi yang tersedia untuk investor yang berhubungan dengan investasi dalam perusahaan tersebut semakin banyak. Sebab itu, perusahaan yang lebih besar kurang memiliki dorongan untuk melakukan manajemen laba dibandingkan dengan perusahaan-perusahaan kecil dan karena perusahaan besar dipandang lebih kritis oleh pemegang saham dan pihak luar. Namun hasil ini tidak konsisten dengan penelitian Anggraeni \& Hadiprajitno (2013) yang membuktikan bahwa ukuran

* Corresponding author's e-mail: dosen01146@unpam.ac.id

http://openjournal.unpam.ac.id/index.php/JIA 
Jurnal Ilmiah Akuntansi Universitas Pamulang - Vol. 9, No. 1, Januari 2021 Oktavianna \& Prasetya

perusahaan atau firm size tidak memiliki pengaruh secara signifikan terhadap manajemen laba. Hal ini terjadi karena setiap perusahaan memiliki kepentingan sama yakni untuk terlihat baik bagi investor dalam memiliki kecenderungan yang sama dalam melakukan laba, baik perusahaan kecil maupun perusahaan besar.

\section{KESIMPULAN}

Hasil penelitian dapat disimpulkan bahwa Komite audit dan firm size secara bersama-sama atau simultan memiliki pengaruh terhadap manajemen laba. Namun Komite audit tidak berpengaruh terhadap manajemen laba, hal ini bisa dikarenakan perusahaan yang memiliki komite audit hanya untuk memenuhi syarat yang diminta oleh pemerintah sedangkan pengawasan internal yang lebih baik belum dapat secara optimal meminimalisir manajer melakukan tindakan manajemen laba.

Firm size berpengaruh secara signifikan terhadap manajemen laba, karena ukuran perusahaan yang semakin besar maka informasi yang tersedia untuk investor yang berhubungan dengan investasi dalam perusahaan perusahaan semakin banyak dan lengkap. Perusahaan yang lebih besar kurang memiliki dorongan untuk melakukan manajemen laba dibandingkan dengan perusahaan-perusahaan kecil dan karena perusahaan besar dipandang lebih kritis oleh pemegang saham dan pihak luar.

\section{DAFTAR PUSTAKA}

Ali, S., \& Adityawarman. (2014). Pengaruh Ukuran Auditor, Auditor Spesialisasi Industri dan Independensi Auditor terhadap Praktik Manajemen Laba pada Perusahaan yang terdaftar dalam Jakarta Islamic Index Tahun 2010-2012. EJournal Universitas Diponegoro, 3(2), 2337-3806.

Anggraeni, Riske M., \& Hadiprajitno, P.Basuki. (2013). Pengaruh Struktur kepemilikan Manajerial, Ukuran Perusahaan dan Praktik Corporate Governance terhadap Manajemen Laba pada Perusahaan Manufaktur yang terdaftar di Bursa Efek Indonesia Tahun 2009-2011. E-journal Universitas Diponegoro, 2(3), 2337-3806.

Dinuka dan Zulaikha. 2014. Analisis Pengaruh Audit Tenure, Ukuran KAP, dan Diversifikasi Geografis Terhadap Manajemen laba. Fakultas Ekonomi dan Bisnis Universitas Diponegoro.

Khurnanto, R. F. \& Syafruddin, M. (2015). Pengaruh Komite Audit dan Audit Eksternal terhadap Manajemen Laba. E-Jurnal Universitas Diponegoro, 4(4), 2337-3806.

Kordriyah \& Fitri, A. (2017). Pengaruh Free Cash Flow dan Leverage terhadap Manajemen Laba. Jurnal Akuntansi, 3(2), 2549-5968.

* Corresponding author's e-mail: dosen01146@unpam.ac.id

http://openjournal.unpam.ac.id/index.php/JIA 
Jurnal Ilmiah Akuntansi Universitas Pamulang - Vol. 9, No. 1, Januari 2021 Oktavianna \& Prasetya

Lestari, Eka., dan Murtanto. (2017). Pengaruh Efektivitas Dewan Komisaris dan Komite Audit, Struktur Kepemilikan, Kualitas Audit terhadap Manajemen Laba. Jurnal Media Riset Akuntansi, Auditing dan Informasi. ISSN 2442- 9708, 17 (2):97-116

Makaombohe, Y.Y. \& Pangemanan, S. S. (2014). Ukuran Perusahaan terhadap Manajemen Laba. Jurnal EMBA, 2(1), 656-665.

Manggau, A. W. (2016). Pengaruh Asimetri Informasi dan Ukuran Perusahaan terhadap Manajemen Laba. Jurnal Ekonomi dan Keuangan. Fakultas Ekonomi dan Bisnis. Universitas Mulawarman, 13(2), 2528-1135.

Nabila, A. \& Daljono. (2013). Pengaruh Proporsi Dewan Komisaris Independen, Komite Audit dan Reputasi Auditor terhadap Manajemen Laba. E-Jurnal Universitas Diponegoro, 2(1).

Riani, E., Umam, K., Saputra, M. C., Sibarani, R. S., \& Prasetya, E. R. (2020). Pengaruh Ukuran Perusahaan, Profitabilitas Dan Auditor Internal Terhadap Audit Delay (Studi Empiris Pada Perusahaan Jasa Sektor Property Dan Real Estate Yang Terdaftar Pada Bursa Efek Indonesia Tahun 20162018). Proceedings Universitas Pamulang, 1(1), 63-74.

Sulistyanto, Sri. (2008). Manajemen Laba Teori dan Model Empiris. Jakarta: PT.Grasindo

Yulianti, E., Anjani, A. D., Nugraheni, L. P., \& Prasetya, E. R. (2020). Pengaruh Investment Opportunity Set, Growth Opportunity, Dan Ukuran Perusahaan Terhadap Kualitas Laba (Studi Empiris Pada Perusahaan Perdagangan Jasa Dan Investasi Yang Terdaftar Di Bei Periode 2016-2018). Proceedings Universitas Pamulang, 1(1), 153-166. 